\title{
Erratum: The self as a lens through which to study religion: Keiji Nishitani's Religion and Nothingness revisited
}

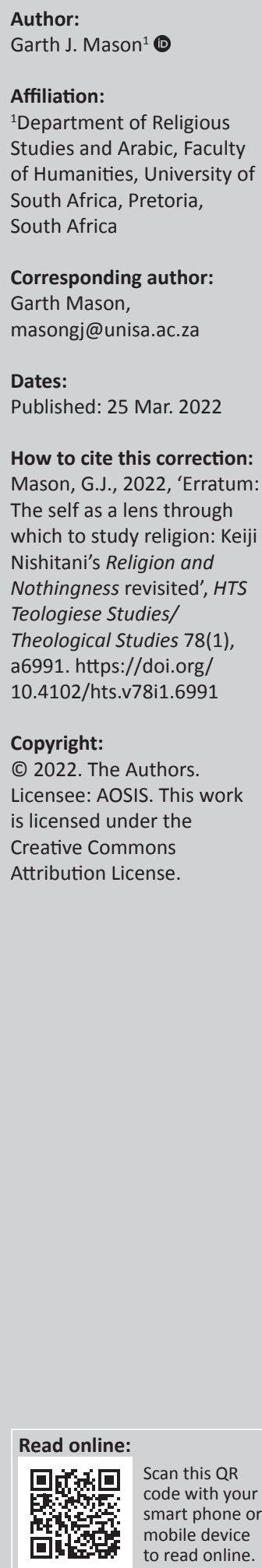

In the original article published, Mason, G.J., 2021, 'The self is as a lens through which to study religion: Keiji Nishitani's Religion and Nothingness revisited', HTS Teologiese Studies/Theological Studies 77(2), a6715. https:/ / doi.org/10.4102/hts.v77i2.6715, the title contained a wording error. The wording error was unintentional. As a result of this, the title is corrected to read 'The self as a lens through which to study religion: Keiji Nishitani's Religion and Nothingness revisited'.

The publisher apologises for this error. The correction does not change the study's findings of significance or overall interpretation of the study's results or the scientific conclusions of the article in any way. 


\section{The self is as a lens through which to study religion: Keiji Nishitani's Religion and Nothingness revisited}

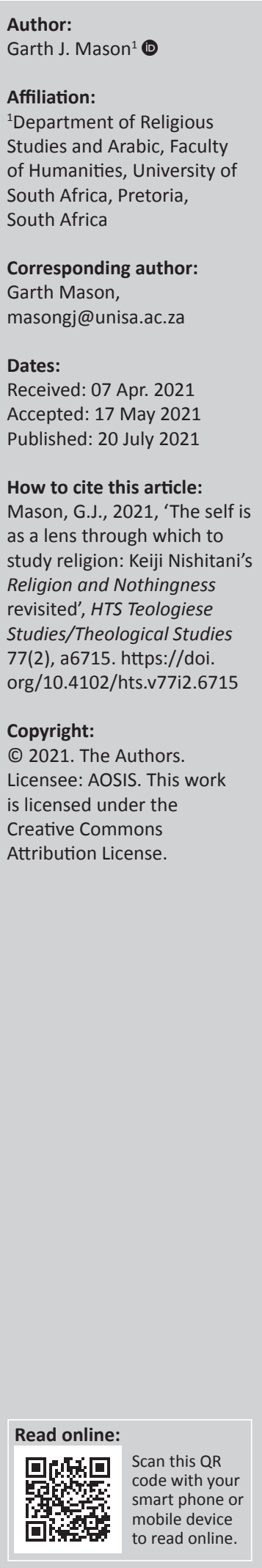

This article offers an analysis of Keiji Nishitani's understanding of the religious self as a window into his wider understanding of religion. It serves two purposes: to motivate for a revisiting of Nishitani's book Religion and Nothingness (1983) and to argue that his ideas offer innovative approaches to contemporary Religious Studies. The self is the focus of Nishitani's understanding of religion. Nishitani argues that the self is in crisis, rooted in the following question: 'For what purpose do I exist?' At the point of our deepest doubt (what he terms 'the Great Doubt') emerges an awareness of nothingness. That paradoxically leads to the potential for conversion: a uniquely religious experience. Nishitani's analysis of religion and the self in crisis is valuable for the study of the religion more broadly because it locates the self as an important focus in the study of religion. Nishitani's argument for the importance of religion and conversion in peoples' lives foreshadowed two contemporary theoretical topics in the study of religion, namely posthumanism and postsecularism. To be human, to be aware of one's death as a human being and the absolute doubt it causes, drives us to understand that we share the same fate as all life in the wider ecology and forces us to recognise that we share our creatureliness with all other life forms. Postsecularism is based on the prevalence of religion globally, despite predictions of its demise by secularists. This article reads the later writings of Derrida in the frame of postsecularism.

Contribution: This article contributes to the current research into religious experience in the field of Religious Studies. It also suggests that the current sociological research of religious expression concentrates on identity advocacy but does not acknowledge the opposite issue of identities in crisis. This article addresses the dearth of research on the latter.

Keywords: Nishitani; self; death; purpose; religion.
Silence, I discover, is something you can actually hear. (Murakami 2005:148)

[The world today] is as furiously religious as it ever was ... is anything but the secularized world that had been predicted (whether joyfully or despondently) ... the shallowness of a culture that tries to get along without any transcendent point of reference. (ed. Berger 1999:2)

This article offers a critical analysis of Keiji Nishitani's understanding of the religious self as a window into his wider understanding of religion. For Nishitani (1983), the self is a lens through which to study religion. His ideas are most comprehensively expressed in his book Religion and Nothingness. At the foundation of Nishitani's (1983) idea of the self is the following question: 'For what purpose do I exist?' (p. 3). For Nishitani (1983), religion is rooted in the core doubt in human lives: the question of the meaning of our existence. At the point of our deepest questioning of ourselves, 'the religious quest awakens in us' (p. 3). At the point of our deepest doubt (what he terms 'the Great Doubt') is an awareness of nothingness. However, at this nexus of radical dissolution, we discover the potential for conversion: a uniquely religious experience (Nishitani 1983:4). Nishitani's analysis of religion is valuable for the study of the religion more broadly because it locates the self as an important focus in the study of religion. There is a complex relationship between the religieux (the followers of a religion, their beliefs and practices) and the enactment of their religion within society and historical context. Even Flood (2004), in his study in asceticism, uses a sociological approach to the religious self embodied in a performance of tradition, which is a religious act (p. 2). Nishitani (1983) usefully reduces the broad materialistic or sociological approach to the study of religion to the utility or role of religion with an individual's life and the wider society (p. 2). Conventional approaches to religion, Nishitani (1983) observes, are concerned with culture, resources and society (p. 2) and are located in historical and sociological approaches. Yet, for Nishitani (1983), religion cannot be fully understood either within the parameters of utility or from a sociological viewpoint. He argues evocatively:

Note: Special Collection: Re-readings of Major Theorists of Religion: Continuities and Discontinuities, sub-edited by Mohammed (Auwais) Rafudeen (University of South Africa). 
Our ordinary mode of being is restricted to these levels of natural and cultural life. But it is in breaking through that ordinary mode of being and overturning it from the ground up, in pressing us back to the elemental source of life where life itself is seen as useless, that religion becomes something we need - a must for human life. (p. 2)

For Nishitani, although religion may not be as essential as food for survival, it is essential in another sense in that its content deals with the root questions of human existence, the purpose of life and its meaning. When daily existence, its activities and goals are stripped away, one perceives the fundamentals or the 'elementals' of existence as well as its purpose. Religion, for Nishitani, is primarily to provide purpose to human beings, not, however, in terms of formal aspects of religion. Rather, he argues that the religious self comes to understand the world, through a process of conversion, as immanently holy. Religion, for Nishitani, is neither philosophical, scientific nor social. Instead, it focusses on the individual's interaction with reality and the cosmos. At the core of this interaction, religion confronts death and its consequence: nihility (Nishitani 1983:3). Although our existences are filled with specific narratives and goals, all individual life comes to an end. Life, its very substance, comes in the end to nothing. This is the problem that religion deals with, according to Nishitani. The focus of religion is therefore unique. Philosophy may come closest to what religion is because of the proximity of philosophy's consideration of metaphysics, and yet religion's concerns reach beyond metaphysics, towards how we engage with the cosmos as intrinsic to our purpose or telos. It is indeed the case that Nishitani is influenced by existential philosophy; however, Nishitani argues that Sartre's sense of nothingness is situated on the side of the ego and never ventures beyond what he terms the 'bankruptcy of the Cartesian ego' (Nishitani 1983:33). Nishitani argues that religious concerns reach beyond the philosophy of what is, to the impact of the immediacy of reality on the self. An experience of this leads to conversion: a common subject of religious discourse. By this, he means more than the adoption of a belief system and its practices. Rather, he alludes to an 'ontological conversion' when the self encounters its essential state in relation to the cosmos (Nishitani 1983:4).

Nishitani's argument for the importance of religion and conversion in peoples' lives foreshadowed two contemporary theoretical topics in the study of religion, namely posthumanism and postsecularism. The resonance in his thinking with these two modern theories suggests that his writing should be reread in the light of these contemporary ideas. Like many posthuman thinkers, Nishitani reflects on the human experience of death, the ultimate end and unavoidable cessation of the personal human experience. In death and the study of death, humanism intersects with posthumanism. To be human, to be aware of one's death as a human being and the absolute doubt it causes, drives us to understand that we share the same fate as all life in the wider ecology and forces us to recognise that we share our creatureliness with all other life forms. This realisation is most powerfully articulated by ecofeminist posthumanist theorists such as Astrida Neimanus (in eds. Asberg \& Braidotti 2018:100), who muses on fluid identities and the radical non-purity of being, and Donna Haraway who considers the vastly interconnected web of all life (and technology) that leads to foregrounding sharing rather than othering (eds. Asberg \& Braidotti 2018:199). For this reason, this article will focus on ecofeminist posthumanism as having the strongest resonances with Nishitani's thinking. Postsecularist theorists share feminist posthumanist concerns in that they recognise the elemental importance of religion for humans that speaks directly to experience and the need for a wider and deeper purpose, as does Nishitani. Postsecular thinking includes the later religiously influenced writings of Jacques Derrida (Abeysekara 2008; Blond 2002). In this article, I will consider the similarities between Derrida's writing and Nishitani's ideas. In the 20th century, secularist theorists argued that secularisation would limit the further development of religion and eventually would usher in the end of the need for religion. The two seminal secularist theorists in the late 20th century were Jürgen Habermas and Peter Berger. Notably, however, the same two theorists (Habermas and Berger) conceded in the late 20th century and early 21st century that religion had grown in global influence, specifically in terms of religious identity, contradicting their previous predictions. Habermas wrote his now-famous essay in 2008, entitled 'An awareness of what is missing: faith and reason in a post-secular age' (Habermas 2010 and in Watson 2014:2). Similarly, Berger (ed. 1999) argues, in the opening chapter in The desecularisation of the world, resurgent religion of the world, that religion has grown rather than declined globally. Church attendance in Western countries is still an integral part of cultural life, religious conflict has increased and religious fundamentalism has global influence. Postsecularism shines a spotlight on the importance of religion in peoples' lives. In this regard, the 'Spiritual But Not Religious' (SBNR) identifying phrase is significant in its foregrounding of spiritual experience and well-being (Carrette \& King 2004). Nishitani also based his understanding of religion on importance of religion in people's lives in offering a conduit for purpose in life. Reading Nishitani alongside Derrida's later post-secularist writings supports my contention that Nishitani is important for contemporary studies of religion.

Nishitani's focus on the importance of religion in people's lives draws attention to religious experience. Recent studies in religion have emphasised the importance of religious experience and initiated a return to the writings of Rudolph Otto, William James, Albert Schweitzer and Friedrich Schleiermacher, to the point where Krech (2020:100) refers approvingly to Schleiermacher's assertion that religion 'is neither thinking nor acting, but intuition and feeling'. In addition, the study of religious experience, particularly that of James (1902), opened the study of religion to investigating subjective spiritual experience and renewed interest in mysticism (Oliver 2009). James' roots in Psychology also, consequently, helped innovate research into the psychology of religion. 
The study of religion from the perspective of experience rather than rationality leads to a focus on the self and being. In both Eastern and Western studies of religion, the self and being have long been studied. For example, Carroll (2007) writes in The Existential Jesus that the Western study of being is locatable in the quest to understand the earliest representation of Jesus in the Gospel of Mark and its foundation texts. Thus begins the quest of the Western psyche (Carrol 2007:1). The Gospel of Mark is particularly relevant because its representation of Jesus opens to his selfdoubt in accomplishing his mission (Carrol 2007:1). The earliest expressions of soul and being are found in Vedic literature (Brihadārnyanaka Upanişad 1965:1). But what Nishitani points out is that the bridge between Eastern and Western notions of being is not as circuitous as it might appear. Nishitani's (1983) book Religion and Nothingness, although Zen in perspective, draws eclectically from Freud, Dostoyevsky, Sartre, Nietzsche and Christianity to explain his concept of the 'Great Doubt' brought on by the experience of nothingness at the foundation of the self (p. 4). Nishitani's emphasis on the experience of self and being links to the contemporary theories of postsecularism and posthumanism in that both theories explore the meaning of being in the present and the future.

After establishing that Nishitani's writing should be considered along with modern theories such as ecofeminist posthumanism and postsecularism, I will argue that Nishitani has much to offer contemporary Religious Studies. Recent Religious Studies tends to follow a sociological perspective that emphasises context and the assertion of religious identity. Crucial to Nishitani's understanding of religion is, however, the conversion of being that is inextricably linked to the radical experience of self-doubt. Nishitani provides a significant alternative view of religious identity as identity in crisis. In this regard, religion is the perfect conduit to examine existential doubt and subsequent conversion. Conversion is not a focus of philosophy, but the idea of conversion is embedded in religious world-views, especially where the experience of nullity gives way to an experience of conversion to a new being. For this reason, I argue that Nishitani has specific value to offer to Religious Studies in the present and the future, particularly in relation to the understanding of conversion and religious identity crisis. Nishitani is presenting a more experientially based idea of conversion than the normative understanding that denotes an adoption of or change to a particular religious belief system that is accompanied by a changed identity. Nishitani's understanding of conversion is linked to his Zen belief when the ego simultaneously experiences its dissolution and the opening up of the wider locus of nothingness that is the basis of all reality. The death of the ego, for Nishitani (1983), heralds 'heaven and earth becoming new' (p. 21).

Religious Studies (perhaps even more than Philosophy) has recently taken an interest in the experiences of self and selfeffacement (Krech 2020:100). In the light of this shift, it behoves us to explore Nishitani's unique focus on the elemental issues of human purpose, conversion and death within religion. At the point where egocentricity collapses, Nishitani (1983) claims, religion nurtures personally supportive elemental reflections on death and living. But, crucially, religion must be understood from the phenomenological and individual perspective of the person asking questions of life's purpose:

[I]t is a mistake to ask 'What is the purpose of religion for us?' ... It is a question that must be broken through by another question coming from within the person who asks it. There is no other road that can lead to an understanding of what religion is and what purpose it serves. (p. 2)

I agree with Nishitani that the study of religion has the most suitable lexicon and critical lens to study the elemental quests for human purpose and conversion (arguably also within the wider conceptual framework of spirituality). Defining elemental thought is difficult but is the proper field of Religious Studies scholars. For Nishitani (1983), elemental thinking is occasioned by the experience of nihility in the face of death or non-existence, which drives wedges between our normal daily thoughts. He asserts that it:

$[R]$ enders meaningless the meaning of life. We become a question to ourselves ... It emerges from the ground of our existence and that very existence has become a question. (p. 4)

At this point, conversion is possible because the individual's understanding of the self reaches an extraordinary depth. Egocentricity dissolves and we stop asking about the use of things for us; instead, we ask 'for what purpose we ourselves exist. Only when we stand at this turning point does the question "What is religion?" really become our own' (Nishitani 1983:4 and 5). Breaking the chains of selfcentredness and opening the horizon onto broad experience of life is a uniquely religious act. From a completely different cultural tradition, Schweitzer (1956), who founded his ethics on elemental thought, comments on the elemental nature of 'Reverence for life':

Elemental thinking is that which starts from fundamental questions about the relations of man to the universe, about the meaning of life, and about the nature of goodness. (p. 260)

Both Schweitzer and Nishitani argue that conversion emerges from within the self's quest to find meaning. It is, according to Nishitani (1983), a religious quest (p. 3). To understand religion, instead of asking the use of religion, Nishitani (1983) maintains that religion must be understood as an indelible necessity when our very lives become a 'question to ourselves' (p. 3), and the religious quest emerges within the self. Religion, paradoxically, allows for the affirmation of the deepest experience of oneself, which is often related to experiencing the divine (or, in Zen Buddhism, nothingness [śünyatā]), whilst simultaneously forgiving the constructed egoic self for its original sin (in Zen Buddhist terms, tanhā [selfish desire]). The nexus of this contradiction emerges, for Nishitani, in the 'Great Doubt': when the egoic self radically questions its own substance, it simultaneously opens to wider creative impulses of life. The self then becomes deeply 
aware of its erroneous thinking as it becomes most aware of the possibility of redemption within a far wider apprehension of life experience (Nishitani 1983:41, 42). The widest experience of reality, which Nishitani (1983), despite being a Zen Buddhist, refers to as God, is a fundamentally impersonally personal (personally impersonal) experience (p. 41) (it would seem for Nishitani that at this deep level of self the personal and impersonal are indistinguishable). This creativity, rooted in the depth of the self, permits the 'sin' of egoic thinking and also ultimately pardons it (Nishitani 1983:44). This is the basis for religious conversion. Its very nature, Nishitani suggests, is inherently religious because to banish it would be to banish the self's core life force and creativity: an impossibility. Despite Nishitani's adherence to Zen Buddhism that excludes any belief in divinity, he affirms that the experience of emptiness paradoxically gives rise to the misconceived egoic self or in theological terms God allows evil to exist because everything is created equally ex nihilo (Nishitani 1983:44).

The omnipresence of emptiness or God (Nishitani uses these terms as synonyms), which makes conversion possible, according to Nishitani, shares aspects of ecofeminist posthumanism that interrogates human/animal constructivism. For example, Lynda Birke and Tora Holmberg write (eds. Asberg \& Braidotti 2018):

The category of 'human' is, ideologically, historically and practically contingent on separation from, yet dependent upon, non-humanity. Similarly, the category of 'animal' is multiple and gendered. Representations structure and are structured by normative narratives about humans, animals, nature and society ... In constructing an identity of 'animal', we produce human exceptionalism. (p. 120)

Ecofeminist posthuman theorists such as Birke and Holmberg reach beyond the human self to affirm connection with all life forms, from the largest to the microbial. This is similar to Nishitani (and Schweitzer) proposing the importance of elemental thought. In this regard, Nishitani draws a distinction between Buddhist nihilism and existential nihilism. Sartre's nothingness differs from Buddhist nothingness in that Buddhism asserts that emptiness itself must be emptied of substance to achieve an experience of absolute nothingness. Sartre, Nishitani (1983) argues, does not do this and consequently the nothingness he propounds remains locked in by egoic desire and categorisation. In absolute nothingness:

$[E]$ verything is now truly empty, and this means that all things make themselves present here and now, just as they are, in their original reality. They present themselves in their suchness, their tathatā. (p. 34)

For both Nishitani and ecofeminist posthumanists, the more the self disinvests from the ego (which is gendered masculine), the more it is able to experience shared creatureliness.

Nishitani's thought also fits into a postsecular framework, particularly with postmodern theorists who bring religious thought into their writings, namely Emmanuel Levinas and
Jacques Derrida. Derrida's (2005) essay The politics of friendship is founded on the equivocal notion of 'perhaps'. The indefinite relation of the self and the other, Derrida (2005) writes:

What is going to come, perhaps, is not only this or that; it is at last the thought of perhaps itself. The arrivant will arrive perhaps, for one must never be sure when it comes to arrivance; but the arrivant could also be the perhaps itself, the unheard-of, totally new experience of the perhaps. Unheard-of, totally new, that very experience which no metaphysician might yet have dared think. (p. 29)

For Derrida, perhaps - the possibility of a longed-for arrival of a friend - is the source of pleasure itself, even more than the arrival will be when it finally happens. So, the condition of possibility of a meaningful connection with the other is itself, the fulfilment of the desire for that connection. This suggestion by Derrida of the resolvability of the borders between self and other resonates of what Nishitani refers to as the 'Great Doubt', for not only is the doubt in the collapse of a substantial self in death, but there is also a condition of possibility of the cessation of the egoic self in relation to the other. For both Nishitani and Derrida, the self and the other are fluid and open. In Derrida's use of 'perhaps' two processes come into play. The first is the facticity of a happening that has causal origins and consequences. In time, things and events have an undeniable existence. The second process is that of things and events emerging and becoming. There is an emerging into actuality, filled with error, initial attempts, the meeting between the self and the arrivant emerging. There is the fluidity of life, its interconnectional and multifaceted causality (Derrida 2005:17). Derrida argues that under such fluid conditions, theological truth cannot occur as a revelation in time. Instead, he confutes the Heideggerian concept of theion (unaccountability) or theiology as a possible alternative. Here Derrida (2005) gestures towards the potential revealability of events and relationships in and through the process of time (p. 19). But Derrida then takes the question a step further towards a horizontal religious ethics by suggesting that there may be an alternative to choosing between theology and theiology. Drawing from Aristotle's Ethics and Nietzsche's Human all too human, he argues that love between people has two attributes: knowledge and action (loving). The two attributes are allied in the interpersonal bond of love (Derrida 2005:8,9) and, within this indelible bond, there is belonging to friendship or communities (p. 80). Loving within the realm of 'perhaps' requires faith in the novelty of the arrivant (p. 29). One loves despite uncertainty. All decisions are accidental within the context, forsaking the autonomous self (p. 68) and yet in faith (p. 21, 40) and in the face of 'perhaps', we love and take responsibility for the other before our own needs. It is in the awareness of the unknowability of the other that we extend our faith. Derrida (2005) writes:

And here, once again, a 'perhaps' arrives to spread disquiet in the opposition itself. The 'perhaps' carries away the extreme alterity, the possibility of this other end, this term which structures no less the antidemocratic provocation, and results in there never being 'enough to say' or 'enough to silence'. (p. 40) 
Derrida's belief in the unknowable other (arrivant) is even more assuredly religious in Levinas' $(1969,1999)$ writings when he describes the other as transcendent, whose needs and recognition we must hold above our own. In his two works, Alterity and transcendence and Totality and infinity, Levinas argues that the relation between self and the other is a transcendence of the ' $\mathrm{I}$ ' into the space of the 'other' in its complete alterity. Levinas (1999) resonates with Nishitani when he writes of 'the conversion of the for-itself into a responsibility for-the-other' (p. 35). For Nishitani (1983), at the point of 'Great Doubt' all things become real including the root cause of the ego. He writes:

At the same time, the cogito of Descartes did not pass through the purgative fires in which the ego itself is transformed, along with all things, into a single Great Doubt. The cogito was conceived of simply on the field of cogito. This [is] why the reality of the ego as such could not but become an unreality. Only after passing through those purgative fires and breaking through the nullity that makes itself present at the ground of the ego, can the reality of the cogito and the sum, together with the reality of all things, truly appear as real. Only then can this reality be actualized and appropriated. (p. 19)

Whilst Nishitani argues for an other-directed spiritual experience as Derrida and Levinas do, he remains within the tradition of Zen Buddhism. In this sense, he is not a postmodern thinker. For him, there is closure in the event of death, and the study of religion is the closest humanity can get to grappling with the unanswered questions of human existence. Do religions fail in terms of how they are able to negotiate the most important question of existence: Why am I here and where am I going? Nishitani does not think so. If we explore religion from the perspective of nothingness, as Nishitani does, we understand how the study of religion takes humanity to the limits of knowledge. He explains this in human terms through the Buddhist concepts of dharma faith and human faith directed to all sentient beings (Nishitani 1983:26).

In contrast to postmodern ideas of the self as open and nonautonomous, the elemental self is not founded on hermeneutics. Elemental knowledge emerges when the ego's ideas of knowledge subside. What emerges is not knowledge as certainty - what the ego wants - but rather 'Great Doubt'. It does not attempt to create order or systems: it is at peace with the great unknowing. For Derrida, meaning is openended, as indicated by his use of the word 'perhaps': there is no closure to meaning. For Levinas, the self opens to the other. To fully grasp the other, the self needs to cease imposing meaning onto the other, and self and other must engage in a never-ending dialogue, which both Levinas and Derrida agree on.

Similarly, Nishitani argues that consciousness is rooted in the egoic self that always interprets the world subjectively; for him, religion approaches humanity from a radical standpoint that is not embedded in egoic consciousness. Rather, the knowledge of religion is rooted in elemental thought, where one does not differentiate between the self and the other, but has an immediate awareness of elemental material (Nishitani 1983:35). If there is a function of religion, it is to take a person out of their ego-centredness and to recognise life, soul and spirit in the other. In this, he resonates with the thinking of Schweitzer (1955), Buber (1958) and Levinas (1999).

Whilst there is resonance between Nishitani's writings and the modern theoretical trends of ecofeminist posthumanism and postsecularism, which aligns him with contemporary thinking, his ideas provide the study of religion with valuable new perspectives on the religious self. There is a contradiction at the root of the religious self. In the first place, in adhering to certain vows and laws, the religieux identifies with a particular group or religion and the cultural expression of a religion that gives identity through practice and belief. On the other hand, the enactment of religious beliefs is often directed towards the universal; for example, the enactments of forgiveness, compassion and love are universal values. I argue that Nishitani's focus on identity in crisis brings a fresh understanding to this contradiction in analysis of religious conversion.

The study of religion from social or cultural frames of reference links concerns of religion with materiality (cf. Chidester 1996; Cresswell 2013; Strijdom 2014). Sociological studies in religious studies lend themselves to studies of religious/cultural identity, the contextual analysis of religion in society and social forms of religious expression. As Nishitani avers, sociological studies of religion provide studies of the role of religion in society. One of the consequences of the social justice movement is to highlight difference and othering, which are very important for the assertion of religious identity. Nishitani would, however, argue that such religious/cultural studies are bound in egoic consciousness. They cannot analyse the nature or roots of conversion or the interiority of the religious quest. Such studies require the analytical tools to study the religious self, such as employing the concept of elemental thought. However, what would a study of religion from an elemental point of view entail? Although sociological studies of religion affirm identity and identity politics, Nishitani offers some clues to what an elemental study of religion comprises. He (1983) focusses on identity in crisis, drawing on Buddhism's critique of the egoic identity and Christianity, specifically Pauline and Jesus' teachings of the dissolution of identity:

The love of which Jesus speaks is just such a sword: 'For whoever would save his life will lose it, and whoever loses his life for my sake will find it' (Matt. 16:25) .... When St Paul speaks being 'inspired by God' (2 Tim. 3:16) he does not mean that we have the Holy Spirit breathed into us, but rather that our very being becomes 'God-breathed' through the breath (spiration) of God himself. (p. 28)

Nishitani (1983) also draws from Western thinkers who focus on the self in crisis. These include Jean-Paul Sartre (pp. 30-35), Fyodor Dostoyevsky (p. 48) and Sigmund Freud (p. xviii). These three writers also focus on the self assailed by questions of ultimate purpose. In fact, Nishitani (1983) returns to 
Sartre's identification of radical doubt of the Cartesian ego (p. 31) to explain the self at the point of awareness of death and meaninglessness (p. 128). Although Descartes, however, established certainty for the ego in God, Sartre places the ego in a state of freedom founded on its own nothingness (Sartre 2005:458). Nishitani (1983) borrows the notion existential doubt from Sartre but sets it in a uniquely Zen concept of 'Great Doubt' that gives expression to the 'basic uncertainty regarding human existence in the world and the existence of the self and others, as well as the suffering that this gives rise to ...' (p. 16). In designating this existential doubt 'Great', Nishitani (1983) alludes to the heightened mode of being where consciousness honestly confronts its own nihility and moves out of egoic consciousness to be 'suspended in nothingness' alongside all beings. (p. 31). It is in his recognition of this heightened mode of existence that Nishitani (1983) shows alertness to the distinction between the study of the function of religion and the necessity of religion as an expression of deep needs of humanity (p. 2) that will add to the complexity and richness to the study of religion.

Rather than viewing individuals as products of social, economic and political forces, Nishitani describes people as expressions of elemental forces, similar to what Schopenhauer refers to as 'Will' (in pessimistic terms); what Hinduism refer to as tman (in optimistic terms); or what African religion calls seriti (the subtleties of living that provide meaning and dignity to life). These terms cannot find a place in the studies of religion that employ a sociological lens. Rather, from a sociological perspective, people are constructed by forces, race, class, ethnicity and so on. The employment of elemental thought as a research tool in the study of religion need not mean a return to an uncritical pre-modern mindset. Rather, elemental can imply what Nishitani (1983) refers to in Zen Buddhist terms as turning the light to what is directly underfoot' (p. 4). By this he means a moment of lingering that exposes the 'meaninglessness of daily activities that lies in wait at the bottom of those very engagements' but paradoxically it is looking at what lies underfoot that brings meaning to life (Nishitani 1983:4). Such studies will need to employ more subtle tools of analysis to reveal how identities in crisis rediscover purpose. The study of religion from an elemental standpoint cannot use what Nishitani (1983) refers to as egoic consciousness that perceives things in their usevalue (p. 1). It is an epistemology constructed from doubt rooted in existence stripped of Cartesian egoic consciousness, which buffers one against the vulnerability of not knowing. For Nishitiani (1983), religion is precisely the opening to elemental depth of the self that is based on fundamental doubt. In his particular Zen style, he explains:

[I]n order for it [one's life as question] to become a real question, one that is asked with the whole self, body and mind, it must be returned to reality itself. (p. 6)

For Nishitani, the lexicon of religion is that of the elemental self. To understand religion is to perceive humanity's crisis of meaning and purpose and the deep psychological/ elemental forces that can bring meaning into the lives of people (Nishitani 1983:5). It is challenging to find words to explain these elemental forces because one is dealing with the immediacy of experience and feeling that occurs at the limits of knowledge - what Nishitani refers to as Existenz and seems analogous to what Derrida writes of in terms of the fluid immediacy of life that results in there never being 'enough to say' or 'enough to silence' (Derrida 2005:40).

If we are to grasp the significance of what postsecularism observes in contemporary societies of the prevalence of religion, I argue (and Nishitani would concur), we require a new language that 'metaphysicians might not yet have dared think' (Derrida 2005:29) as Derrida writes about the deepest elemental forces of the self. Similarly, ecofeminist posthumanist theorists write of deep interconnectedness of bios or life. Although we are culturally embodied, we are also deeply set within the wider ecology, a fact that the binarism of Western thought conceals. As ecofeminist posthumanists, Lynda Birke and Tora Holmberg write, ' $[i] n$ constructing an identity of "animal", we produce human exceptionalism' (in eds. Asberg \& Braidotti 2018:120). It is indeed in the realisation of a need for a new metaphysic that does not privilege closed systems of meaning over otherness that Nishitani, the later Derrida writings and ecofeminist posthumanists find resonance. In terms of the latter realisation, this article needed to be written in less scientific and more explorative mode allowing for the constituents of a new metaphysic to be teased out.

In Nishitani's turning a sharp focus onto life lived with immediacy and a continuous awareness of death to find meaning and purpose, he forces us to consider our creatureliness from its widest possible ecological framework. A language that can explore the elemental aspects of religion must explore the qualities inherent in religions.

This article has critically explored Nishitani's understanding of religion as lens into investigating the egoic self, its demise and conversion to a new mode of being. Nishitani's ideas blend in appropriately with current theories of postsecularism and ecofeminist posthumanism. In looking at echoes of Nishitani's thinking in Derrida's (2005) later writings (as an example of postsecularism) and ecofeminist posthumanist writers such as Asberg and Braidotti (eds. 2018), we can see possible ways in which elemental knowledge can be employed in the study of religion. At the foundation of the self is nothingness and this is the nexus of the spiritual experience of the self when the divine or reality becomes apparent to human awareness, according to Nishitani. The contemplation of the soul once was the territory of philosophy and theology when the divide between theology and philosophy was much more porous. Religious Studies could learn from Nishitani's focus on the religious self because of its universal coverage of all religions and its focus on religion from a human perspective, rather than a divine approach as in theology. Ultimately, I argue that Nishitani's understanding of religion as 
grounded in elemental thought and expressing the very real need for humanity to experience conversion to a larger and wider life purpose can provide Religious Studies with a rich vein of research into humanity's deepest needs, which the discipline is uniquely equipped to explore.

\section{Acknowledgements Competing interests}

The author declares that he has no financial or personal relationships that may have inappropriately influenced him in writing this article.

\section{Author's contributions}

G.J.M. is the sole author of this research article.

\section{Ethical considerations}

This article followed all ethical standards for research without direct contact with human or animal subjects.

\section{Funding information}

This research received no specific grant from any funding agency in the public, commercial or not-for-profit sectors.

\section{Data availability}

Data sharing is not applicable to this article as no new data were created or analysed in this study.

\section{Disclaimer}

The views and opinions expressed in the article are those of the author and do not necessarily reflect the official policy or position of any affiliated agency of the author.

\section{References}

Abeysekara, A., 2008, The politics of post-secular religion: Mourning secular futures, Columbia University Press, New York, NY.

Asberg, C. \& Braidotti, R. (eds.), 2018, A feminist companion to the posthumanities, Springer, Cham.

Berger, P.L. (ed.), 1999, The desecularisation of the world, resurgent religion of the world, Eerdmanns Publishing, London.

Blond, P., 2002, Post-secular philosophy: Between philosophy and theology, Routledge, New York, NY.

Brihadārnyanaka Upanișad (Commentary Śankarācārya), 1965, Advaita Ashram, Calcutta.

Buber, M., 1958, I and Thou, T \& T Clarck, Edinburgh.

Carrette, J.R. \& King, R., 2004, Selling spirituality: The silent takeover of religion, Routledge, London.

Carroll, J., 2007, The existential Jesus, Counterpoint, Berkley, CA.

Chidester, D., 1996, Savage systems: Colonial and comparative religion in Southern Africa, University of Cape Town Press, Cape Town.

Cresswell, P., 2013, The invention of Jesus: How the church rewrote the New Testament, Watkins Publishing. London.

Derrida, J., 2005, The politics of friendship, Verso, London.

Flood, G., 2004, The ascetic self: Subjectivity, memory and tradition, Cambridge University Press, Cambridge.

Habermas, J., 2010, An awareness of what is missing: Faith and reason in a postsecular age, Polity Press, Cambridge.

James, W., 1902, The varieties of religious experience: A study of human nature, Oxford University Press, Oxford.

Krech, V., 2020, 'Relational religion: Manifesto for a synthesis in the study of religion', Religion 50(1), 97-105. https://doi.org/10.1080/0048721X.2019.1686847

Levinas, E., 1969, Totality and infinity: An essay on exteriority, Duquesne University Press, The Hague.

Levinas, E., 1999, Alterity and transcendence, Columbia University Press, New York, NY. Murakami, H., 2005, Kafka on the shore, Vintage, London.

Nishitani, K., 1983, Religion and nothingness, transl. J. Van Bragt, University of California Press, London.

Oliver, P., 2009, Mysticism: A guide for the perplexed, Continuum, London.

Sartre, J.P., 2005, Being and nothingness: An essay on phenomenology ontology, Routledge, London.

Schweitzer, A., 1955, Civilization and ethics, Adam \& Charles Black, London.

Schweitzer, A., 1956, My life and thought: An autobiography, George Allen \& Unwin, London.

Strijdom, J., 2014, 'Uses of social theory in comparative religious studies: Assessing Chidester's sociological analysis of 'wild religion in post-Apartheid South Africa', Journal for the Study of Religion 27(2), 10-24.

Watson, P., 2014, The age of nothing: How we have sought to live since the death of God, Weidenfeld \& Nicolson, London. 